\title{
Sculpting Factors of Entrepreneurship among University Students in Indonesia
}

\author{
Zakky Zamrudi, Farida Yulianti
}

\begin{abstract}
A B S T R A C T
Objective: The objective of this article is to investigate students as a young generation and their intention to start their own business by analysing the internal and external factors of entrepreneurial intentions in Indonesia.

Research Design \& Methods: The research sample included 652 undergraduate students spread across universities on the five largest islands in Indonesia collected using an online survey form sent using email and group chat. The collected data was analysed by using partial least square-structural equation modelling (PLS-SEM) to investigate the proposed hypotheses in the model.
\end{abstract}

Findings: The results indicated that from the structural model, we confirmed that entrepreneurial self-efficacy shows non-significant results on entrepreneurial intention. However, the most considerable effect of the supporting condition demonstrated better results on entrepreneurial self-efficacy rather than on behavioural control.

Implications \& Recommendations: The non-significance effect of entrepreneurial selfefficacy on entrepreneurial intention indicated that having sufficient knowledge regarding entrepreneurship is not enough without the confidence to apply it.

Contribution \& Value Added: From the empirical evidence, this research has two implications for educators: it is crucial to improve student creativity and to increase the role of external stakeholders to develop entrepreneurial spirit among the students.

\begin{tabular}{|c|c|}
\hline $\begin{array}{l}\text { Article type: } \\
\text { Keywords: }\end{array}$ & $\begin{array}{l}\text { research article } \\
\text { supporting condition; entrepreneurial self-efficacy; perceived behav- } \\
\text { ioural control; entrepreneurial intention }\end{array}$ \\
\hline JEL codes: & $A 20, I 23,125, L 26, L 31$ \\
\hline Received: $22 \mathrm{~S}$ & Accepted: 10 March 2020 \\
\hline
\end{tabular}

Suggested citation:

Zamrudi, Z., \& Yulianti, F. (2020). Sculpting Factor of Entrepreneurship Among University Students in Indonesia. Entrepreneurial Business and Economics Review, 8(1), 33-49. https://doi.org/10.15678/EBER.2020.080102 


\section{INTRODUCTION}

Entrepreneurship has received considerable interest in recent decades, particularly after the rise in development of information systems. The ease of information dissemination and information seeking across platforms created a new stream of business players (Sentanu, Zamrudi, \& Praharjo, 2019). Information and technology development is currently able to facilitate communication directly person-to-person by using the available platforms, including handling payment, knowledge sharing, reporting, security services, monitoring, and many more (Zamrudi, Karim, Faridha, Maharani, \& Kuraesin, 2019). This not only allows large firms to reach a mass market but also provides access for small businesses. Information analysis is mostly discussed in the academic environment and in entrepreneurial forums (Franke \& Lüthje, 2004).

The entrepreneurial atmosphere in Indonesia demonstrated beneficial conditions during recent decades. The newest data from the Ministry of Cooperatives and Small and Medium-Sized Enterprise (SME) of the Republic of Indonesia, demonstrated a satisfactory ratio of SME growth by $14.92 \%$ or an increase from 52.76 million units of SMEs in 2010 to 62.92 million units by the end of 2017 (Ministry of Cooperatives and SMEs, 2018; Ministry of Cooperatives and SMEs, 2016). This data also demonstrated that $99.99 \%$ of the current SME market shares come from Indonesian citizens. The number indicates that the existing market conditions depend on the national supply and demand rather than the international supply and demand. The average owner of SMEs in Indonesia is mostly at the youngadult age between 14 to 40 years old (Directorate of Cooperatives and SMEs Development, 2016). However, from the young-adult population of the SME owners above, most of them are of the age of 27 years to their mid30s.

In today's competitive conditions, the topics of entrepreneurship are becoming a concern for many stakeholders, including universities. University curricula have focused on nurturing entrepreneurship in various countries, including Indonesia. University graduates in Indonesia are also required to understand the concept of entrepreneurship through formal education prepared in the university curriculum.

Universities are considered as a great environment to develop the potential talent of a student and their entrepreneurial spirit. This role remains undeniable in the strengthening of the entrepreneurial intention of its students (Okręglicka, Havierniková, \& Mynarzová, 2013). Many universities have begun offering entrepreneurship departments or at least offering entrepreneurship courses in their curricula in order to promote entrepreneurship culture (Mat, Maat, \& Mohd, 2015). The expected results are for the student to be educated with entrepreneurial information so that they can become potential candidates for future entrepreneurial activities. Most advanced countries began including entrepreneurial studies in their curricula decades ago, which commonly arose from European and American countries (Franke \& Lüthje, 2004). Many factors could increase the knowledge of entrepreneurship culture among university students, including the internal and external environment, self-efficacy, and self-esteem.

A previous study implied that there is another integrated causal chain between the supporting conditions, entrepreneurial self-efficacy, perceived behaviour control, and entrepreneurial intention. The study conducted by Yurtkoru, Kabadayı Kuşcu, and Doğanay, (2014) indicated that the relational supports mostly reflect the most influential factor in 
determining student entrepreneurial intention. The study suggested that a more contextual factor would yield better results. A study between three universities in Vienna, Munich, and MIT found that there was a correlation between external and internal factors in developing student entrepreneurial intention. This study suggested that the exiting variable can be tested to reveal the most influential factor among the proposed variables (Franke \& Lüthje, 2004). It is also essential to understand the "reality" vs. "perception" that reflects the experience as perceived by the student.

To understand the concept, one study determined a specific group of data sources and created more specific indicators of the proposed variables for the supporting conditions and entrepreneurial intention (Turker \& Selcuk, 2009). There is a possibility to find a second-order variable that is derived from the first order construct. It is essential to include the fundamental nature of entrepreneurship education rather than focusing on a specific context. Universities have to contribute to increasing the entrepreneurial spirit by proposing a particular curriculum related to entrepreneurship (Greblikaite, Sroka, \& Gerulaitiene, 2016). Specifically, the findings from Cape Town, Africa showed that there is a significant effect in increasing the student entrepreneurial intention through focusing more on student self-efficacy. However, a larger selection of data sources may give a better understanding of the longitudinal results of entrepreneurial intention studies (Kalitanyi \& Bbenkele, 2019).

This study proposed a model to investigate and understand the factors that may sculpt and cultivate the entrepreneurial spirit in higher education students in Indonesia. The study proposed four constructs that consisted of an antecedent and results variable. The antecedent variable consisted of a supporting condition; entrepreneurial self-efficacy; and perceived behavioural control. The results variable in this study was the entrepreneurial intention.

This study was designed to detail the factors that interest the students in Indonesia to start their own business. This research used an empirical approach employing partial least square-structural equation modelling (PLS-SEM) data analysis to explain the interactive model of the proposed constructs. The research contribution of this study consists of two main points. The first is to give a review of the literature of entrepreneurial attractiveness, particularly those studies related to university students. The second is the empirical part, which tries to fill the gap regarding the importance of entrepreneurial education in higher education by comparing the two paths in the proposed model. The results of this study are expected to give meaningful insight to create an appropriate milestone into entrepreneurial-based education at the university level in Indonesia.

\section{LITERATURE REVIEW}

Among the factors that determine entrepreneurial self-efficacy, the perceived impact of formal learning has the most significant effect. Formal academic programs can have a positive impact on students' intentions to start entrepreneurship activities. Some scholars have pointed out that entrepreneurship education tends to focus on the technical aspects of entrepreneurship and pays little attention to the knowledge of the potential entrepreneurs, including their ideas, beliefs, and intentions (Zhao, Hills, \& Seibert, 2005). Lüthje and Franke (2003) suggested that policymakers and universities need to encourage the programs to step-up their efforts to introduce education, research, and resource planning 
for entrepreneurship. The study of Türker and Selçuk (2009) indicated that higher education has a positive impact on entrepreneurship intentions. According to their research, college education had a positive effect on entrepreneurship intentions.

Franke and Lüthje (2004) compared MIT with two German-speaking universities (the Vienna University of Economics and Business Administration and the University of Munich). They found a unique entrepreneurial model in these universities. Compared with the Massachusetts Institute of Technology, the students from the German speaking universities were not as willing to start a business. According to their cross-cultural studies, Moriano, Gorgievski, Laguna, Stephan, and Zarafshani (2012), indicated that educational programs should pay special attention to affecting students' attitudes toward entrepreneurship positively.

According to Henderson and Robertson (2000), education is often criticized for its separation from the real-world, but educators were considered to encourage people to pursue the choice of entrepreneurship as a profession. According to Türker and Selçuk (2009), decisions about career choice for adolescents varied depending on their family and friends. However, they found that a supportive relationship did not significantly affect entrepreneurs' intentions. Relationship support resembles subjective norms because it reflects the recognition of family and friends. Some empirical studies demonstrated that subjective norms are not relevant when interpreting entrepreneurial intention in the Theory of Planned Behaviour (TPB) model; however, they can have an indirect effect on the entrepreneurial intention by affecting the perceived behavioural control (Liñán, 2008; Liñán \& Chen, 2009).

The Global Entrepreneurship Report (2012) emphasizes the importance of a supportive cultural and institutional environment for entrepreneurship. According to Davis (2011), many governments seem to encourage entrepreneurship without providing a supportive environment for entrepreneurs. Policy recommendations have led to increased labour flexibility, communication, open markets, increased social entrepreneurship, and the elimination of bureaucracy and red tape (Kelley, Singer, \& Herrington 2012). He believes there is need for a culture that encourages hard work and creativity, not politics. Governments that raise economic issues rather than political interests promote entrepreneurship. Research by Türker and Selçuk (2009) suggested that entrepreneurs have a positive impact on corporate intentions, encouraging private, public, and non-governmental organizations to participate in entrepreneurial activities.

This has prompted governments to provide more skills, resources, and support, especially in developing countries, such as Yemen (Zolait, 2014). The possible reason for the rise of perceived behavioural control could be the educational support, relational, or structural support (Karimi, Biemans, Lans, Chizari, \& Mulder, 2014). Saeed, Yousafzai, Yani-De-Soriano, and Muffatto (2013), found that the supporting conditions, such as educational, relational, and structural support can foster entrepreneurial self-efficacy. Therefore, hypotheses 1 and 2 were developed as follows:

H1: The impact of the Supporting condition significantly affects entrepreneurial self-efficacy.

H2: The impact of the Supporting condition significantly affects the perceived behavioural control.

The intention remains the best indicator of human behaviour (Heuer \& Kolvereid, 2014; Krueger \& Carsrud, 1993). According to the Theory of Planned Behaviour (TPB) 
model, goals are defined by personal standards and social relationships (Ajzen, 2002). Selfefficacy affects individual decisions in terms of physical exercise at work, objective levels, stability, and performance (Baron \& Kenny, 1986; Hayes, 2009). Adelekan, Williamson, Atiku, and Ganiyu (2018), performed an empirical analysis between social entrepreneurship education and student attitudes to the development of social institutions in Nigeria. The results demonstrated that there is an essential positive relationship between the selfefficacy of Nigerian entrepreneurs and the college students' desire for social entrepreneurship. Therefore, the high level of self-efficacy of this initiative is related to the intention of college students to create social institutions.

According to a study by Kalitanyi and Bbenkele (2019), their goal was to measure awareness of the role of self-efficacy in improving the entrepreneurship intentions of college students. The study also showed that self-efficacy could influence entrepreneur success. Perceived creativity and learning is a vital prerequisite to be an entrepreneur (Laguía, Moriano, \& Gorgievski, 2019). To improve student entrepreneurial intentions will require steps to strengthen factors, such as the business environment, risks, difficulties, and predictability of various outcomes.

The study on the United States does not imply any significant relation between the entrepreneurial self-efficacy on entrepreneurial intention as another aspect is required to understand the feasibility aspect of the businesses (Fuller, Liu, Bajaba, Marler, \& Pratt, 2018). Therefore, hypothesis 3 is as follows:

H3: Entrepreneurial self-efficacy positively affects the entrepreneurial intention.

Perceived behavioural control (PBC) is related to the belief that companies can carry out a behaviour under investigation and the belief that people control this behaviour (Ajzen, 2002). PBC is concerned about the validity of the actions that individuals generally take concerning the activities they can judge (Fayolle, Gailly, \& Lassas-Clerc, 2006). PBC is similar to Bandura's theory of self-efficacy (1982). This indicates the belief that an individual can accomplish a task (Bandura, Freeman, \& Lightsey, 1997). Ajzen (2002), however, argues that the $\mathrm{PBC}$ is a broader concept of self-efficacy as it includes control measures.

Self-government is defined as "awareness of those who believe that the most important people should not carry out the problems in question" (Utami, 2017). PBC is considered a social-belief in shaping the individual belief in the ability to perform a specific behaviour in business (Doanh \& Bernat, 2019). Engle et al. (2010) stated that PBC could successfully predict the entrepreneurial intention among university students in seven countries. A study conducted with engineering students in Austria indicated that there is no significant relationship between PBC and entrepreneurial intention. Therefore, hypothesis 4 was developed as follows:

H4: Perceived behavioural control affects entrepreneurial intention.

Based on the previous research and the literature mentioned above, Figure 1 depicts the proposed conceptual model of our current research.

\section{MATERIAL AND METHODS}

This study is an empirical study that used an explanatory approach to explain the proposed model in order to increase the understanding of student intentions regarding entrepreneurship. The factors that influenced the entrepreneurial intentions included the support- 
ing condition, entrepreneurial self-efficacy, and perceived behavioural control. The proposed model is shown in Figure 1.

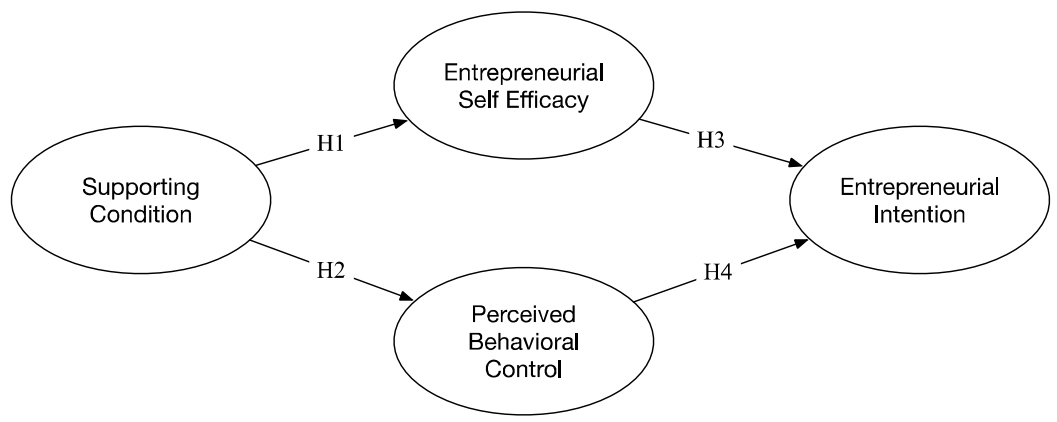

Figure 1. The Proposed Model of Factors Affecting Entrepreneurial Intention

Source: adapted from Kalitanyi and Bbenkele, 2019; Natalia and Rodiah, 2019; Qiao and Huang, 2019; Huang and Zhou, 2018; Venema et al., 2015; Yurtkoru et al., 2014; Esfandiar et al., 2005.

\section{Instrument Development}

This research proposed four constructs, namely the supporting condition, entrepreneurial self-efficacy, perceived behavioural control, and entrepreneurial intention. In measuring the proposed constructs, this research built a set of research instruments that consisted of a list of questions. The instrument was measured using seven point semantic differential scales to provide a wide span of choice for two contrasting answers. The supporting condition consisted of three second-order dimensions consisting of educational support, relational support, and structural support. Entrepreneurial self-efficacy was measured using two second-order dimensions consisting of creativity and learning. The developed instrument used in this study can be found in appendix $A$ in the end of this paper.

\section{Sample and Data Collection}

The data were collected through a survey conducted in Indonesia in December 2018. The target respondents were higher education students, both in undergraduate and postgraduate programs in Indonesia, from 28 universities from the five biggest islands in Indonesia, including Java, Sumatra, Kalimantan, Sulawesi, and Papua. The question instrument was distributed using an online form questionnaire distributed to the population randomly. Before the primary studies, pilot research was conducted to ensure the wording was clearly understood by the respondents while ensuring the instrument validity and reliability for complete data collection. For the primary data collection, there were a total of 700 students involved in this study from various universities. The online forms were linked to the student groups across social media platforms to increase the ease of survey completion, including WhatsApp groups, Facebook groups, Instagram pages, twitter, etc. Due to incompletion of the form, several data were discarded, resulting in 653 usable responses. The valid data included 250 male students and 403 female students. The age of respondents ranged from 17 to 42 years old, with an average age of 19 years old. 


\section{Data Analysis}

The proposed construct employed structural equation modelling (SEM) as recommended by previous studies. This has many advantages over other methods (Amaro \& Seabra, 2015; Hair, Risher, Sarstedt, \& Ringle, 2018; Hair, Ringle, \& Sarstedt, 2013; Straub, Boudreau, \& Gefen, 2004). SEM provided a comprehensive analytical tool to measure the path analysis and factor analysis while ensuring the validity and reliability for internal consistency. This research employed partial least square-SEM (PLS-SEM) over other methods. Sample size and model specifications for rarely conducted research are often issues with SEM, while PLS can handle the problem smoothly (Hair et al., 2018). The nature of this research was an exploratory analysis where PLS was appropriate to analyse the model and test the hypothesis.

This research used a 500 bootstrapping resample method for exploratory analysis as recommended by prior research in testing the causal chain hypothesis. The results indicated the estimates for loading factors of each item, indicator, and constructs based on the confidence interval level $(\mathrm{Cl})$, allowing determination of the factor stability (Hair, Ringle, \& Sarstedt, 2011).

\section{RESULTS AND DISCUSSION}

The results section in this article will provide proof of the construct validity, reliability, structural model, and a discussion. The reliability and validity of the constructs will show the internal consistency of the current measurement model. In the next description, the measurement model emphasizes the causal chain described using path analysis in PLSSEM. The discussion section attempts to relate the findings with previous studies associated with this study. The detailed results and discussion section are presented as follows.

\section{Reliability \& Validity}

Reliability in a survey reflects the stability of the measures it uses. Table 1 displays the results of the reliability analysis assessed by using composite reliability and the Cronbach alpha. In evaluating the reliability our methods involved the composite reliability where the accepted value should exceed 0.70 , which needed the Cronbach alpha to interpret the results (Hajli, 2015; Hajli \& Lin, 2016). According to Table 1 below, all of the proposed constructs met the cut-off value of the reliability assessment. The cut-off value of the composite reliability must be $>0.7$, and the Cronbach alpha cut-off value must indicate a number $>0.68$.

Validity in a survey depicts the item's ability to measure the phenomena. The validity measures used two methods, the convergent validity and discriminant validity. Table 1 shows the convergent validity test provided by the average variance extracted (AVE) results. The AVE cut-off value must be $>0.5$, which all of the constructs met. The discriminant validity, as shown in Table 2, indicates that all of the constructs met the Fornell-Larcker criterion that the crossdiagonal results should be higher than the off-diagonal results (Hair et al., 2018; Wong, 2013). The construct including Entrepreneurial Intention (EI); Entrepreneurial Self Efficacy (ESE); Goal (GOL); Implementation (IMP); Creativity (CRE); Educational (EDU); Learning (LRN); Perceived Behavioural Control (PBC); Relational (REL); Structural (STR); Supporting Condition (SC). 
Based on these results, all the constructs passed the validity and reliability evaluation. These results suggested that the data could then be processed for further analysis.

Table 1. Source of Construct, Reliability, and Validity

\begin{tabular}{|c|c|c|c|c|c|}
\hline Sources & Code & Loading & CR & AVE & Alpha \\
\hline \multirow{4}{*}{$\begin{array}{l}\text { Educational } \\
\text { (Kalitanyi \& Bbenkele, 2019; Yurtkoru et al., 2014) }\end{array}$} & ed1 & 0.910 & \multirow[t]{4}{*}{0.886} & \multirow[t]{4}{*}{0.922} & \multirow[t]{4}{*}{0.747} \\
\hline & ed2 & 0.883 & & & \\
\hline & ed3 & 0.873 & & & \\
\hline & ed4 & 0.788 & & & \\
\hline \multirow{3}{*}{$\begin{array}{l}\text { Relational } \\
\text { (Venema et al., 2015; Yurtkoru et al., 2014) }\end{array}$} & rel1 & 0.890 & \multirow[t]{3}{*}{0.805} & \multirow[t]{3}{*}{0.882} & \multirow[t]{3}{*}{0.716} \\
\hline & rel2 & 0.720 & & & \\
\hline & rel3 & 0.915 & & & \\
\hline \multirow{3}{*}{$\begin{array}{l}\text { Structural } \\
\text { (Venema et al., 2015; Yurtkoru et al., 2014) }\end{array}$} & str1 & 0.874 & \multirow[t]{3}{*}{0.827} & \multirow[t]{3}{*}{0.743} & \multirow[t]{3}{*}{0.897} \\
\hline & str2 & 0.894 & & & \\
\hline & str3 & 0.817 & & & \\
\hline \multirow{7}{*}{$\begin{array}{l}\text { Creativity } \\
\text { (Esfandiar et al., 2019; Zhao et al., 2005) }\end{array}$} & cre1 & 0.846 & \multirow[t]{7}{*}{0.883} & \multirow[t]{7}{*}{0.594} & \multirow[t]{7}{*}{0.910} \\
\hline & cre2 & 0.837 & & & \\
\hline & cre3 & 0.823 & & & \\
\hline & cre4 & 0.826 & & & \\
\hline & cre5 & 0.713 & & & \\
\hline & cre6 & 0.735 & & & \\
\hline & cre7 & 0.577 & & & \\
\hline \multirow{4}{*}{$\begin{array}{l}\text { Learning } \\
\text { (Yurtkoru et al., 2014; Zhao et al., 2005) }\end{array}$} & Irn1 & 0.697 & \multirow[t]{4}{*}{0.714} & \multirow[t]{4}{*}{0.542} & \multirow[t]{4}{*}{0.824} \\
\hline & $\operatorname{Irn} 2$ & 0.740 & & & \\
\hline & Irn3 & 0.831 & & & \\
\hline & Irn4 & 0.666 & & & \\
\hline \multirow{6}{*}{$\begin{array}{l}\text { Perceived Behavioural Control } \\
\text { (Natalia \& Rodhiah, 2019; Qiao \& Huang, 2019; } \\
\text { Yurtkoru et al., 2014) }\end{array}$} & $\mathrm{pbc1}$ & 0.804 & \multirow[t]{6}{*}{0.875} & \multirow[t]{6}{*}{0.616} & \multirow[t]{6}{*}{0.906} \\
\hline & $\mathrm{pbc2}$ & 0.824 & & & \\
\hline & pbc3 & 0.802 & & & \\
\hline & pbc4 & 0.789 & & & \\
\hline & $\mathrm{pbc5}$ & 0.786 & & & \\
\hline & pbc6 & 0.698 & & & \\
\hline \multirow{2}{*}{$\begin{array}{l}\text { Goal (Huang \& Zhou, 2018; Qiao \& Huang, 2019; } \\
\text { Yurtkoru et al., 2014) }\end{array}$} & gol1 & 0.922 & \multirow[t]{2}{*}{0.814} & \multirow[t]{2}{*}{0.843} & \multirow[t]{2}{*}{0.915} \\
\hline & gol2 & 0.914 & & & \\
\hline \multirow{3}{*}{$\begin{array}{l}\text { Implementation (Natalia \& Rodhiah, 2019; Qiao \& } \\
\text { Huang, 2019; Zhao et al., 2005) }\end{array}$} & imp1 & 0.890 & \multirow[t]{3}{*}{0.846} & 0.765 & 0.907 \\
\hline & imp2 & 0.884 & & & \\
\hline & imp3 & 0.849 & & & \\
\hline
\end{tabular}

Source: adapted from Kalitanyi and Bbenkele, 2019; Natalia and Rodiah, 2019; Qiao and Huang, 2019; Huang and Zhou, 2018; Venema et al., 2015; Yurtkoru et al., 2014; Esfandiar et al., 2005; detail item in appendix A.

\section{Structural Model}

The estimation results of the PLS path analysis are shown in Figure 2. According to the results, the four hypotheses indicated that three of them demonstrated a significant effect, while the other showed a non-significant effect at the 0.05 level. The proposed construct's ability to explain the antecedent variable on the results variable was assessed using the R square and structural path loading. The R square indicated that the supporting 
Table 2. Square correlations among the constructs

\begin{tabular}{|c|c|c|c|c|c|c|c|c|c|c|c|}
\hline$><$ & EI & ESE & GOL & IMP & CRE & EDU & LRN & PBC & REL & STR & SC \\
\hline EI & 0.946 & & & & & & & & & & \\
\hline ESE & 0.347 & 0.964 & & & & & & & & & \\
\hline GOL & 0.897 & 0.376 & 0.918 & & & & & & & & \\
\hline IMP & 0.746 & 0.301 & 0.709 & 0.875 & & & & & & & \\
\hline CRE & 0.340 & 0.694 & 0.369 & 0.294 & 0.771 & & & & & & \\
\hline EDU & 0.170 & 0.431 & 0.192 & 0.145 & 0.464 & 0.864 & & & & & \\
\hline LRN & 0.257 & 0.814 & 0.278 & 0.226 & 0.629 & 0.241 & 0.736 & & & & \\
\hline PBC & 0.736 & 0.469 & 0.729 & 0.654 & 0.448 & 0.227 & 0.378 & 0.785 & & & \\
\hline REL & 0.342 & 0.483 & 0.385 & 0.272 & 0.500 & 0.443 & 0.306 & 0.367 & 0.843 & & \\
\hline STR & 0.166 & 0.426 & 0.231 & 0.107 & 0.461 & 0.613 & 0.227 & 0.280 & 0.579 & 0.826 & \\
\hline SC & 0.263 & 0.534 & 0.313 & 0.205 & 0.568 & 0.859 & 0.307 & 0.343 & 0.772 & 0.867 & 0.716 \\
\hline
\end{tabular}

Note: EI - Entrepreneurial Intention; ESE - Entrepreneurial Self Efficacy; GOL - Goal; IMP - Implementation; CRE - Creativity; EDU - Educational; LRN - Learning; PBC - Perceived Behavioural Control; REL - Relational; STR - Structural (STR; SC - Supporting Condition.

Source: own study based on Smart-PLS output, 2019.

condition had a satisfactory result in explaining the entrepreneurial self-efficacy for $28.5 \%$. However, the supporting condition demonstrated enough effect in explaining the perceived behavioural control for $11.7 \%$. The ability of entrepreneurial self-efficacy and perceived behavioural control showed a satisfactory result in explaining the entrepreneurial intention for $54.2 \%$. The following relations explained the relationship among constructs, both in a direct relationship and indirect relationship.

The empirical data testing was conducted through a bootstrapping method to reveal the significant relations among the constructs using t-tests reflected by the critical ratio. The criteria that demonstrated if any hypothesis showed a statistically significant effect is indicated by the critical ratio (CR) value should exceed 1.96, as shown in Figure 2 . The bootstrapping method used a 500 resample method with 652 cases per sample. Based on the findings, it is indicated that there is one hypothesis that demonstrated a non-significant result, that is, the effect of entrepreneurial self-efficacy on entrepreneurial intention. Therefore, H1, H2, and H4 were supported, while H3 was not supported.

According to the path coefficient from Figure 2, the effect of the supporting condition on entrepreneurial self-efficacy (0.534) was stronger than that of the perceived behavioural control (0.343). The effect of perceived behavioural control (0.736) was more significant than that on entrepreneurial self-efficacy (0.001). The indirect effect of the supporting condition on entrepreneurial intention through perceived behavioural control (0.252) demonstrated a significant effect, while by entrepreneurial self-efficacy showed a non-significant indirect effect $(0.001)$. This result indicates that the perceived behavioural control was more critical than the entrepreneurial self-efficacy. 


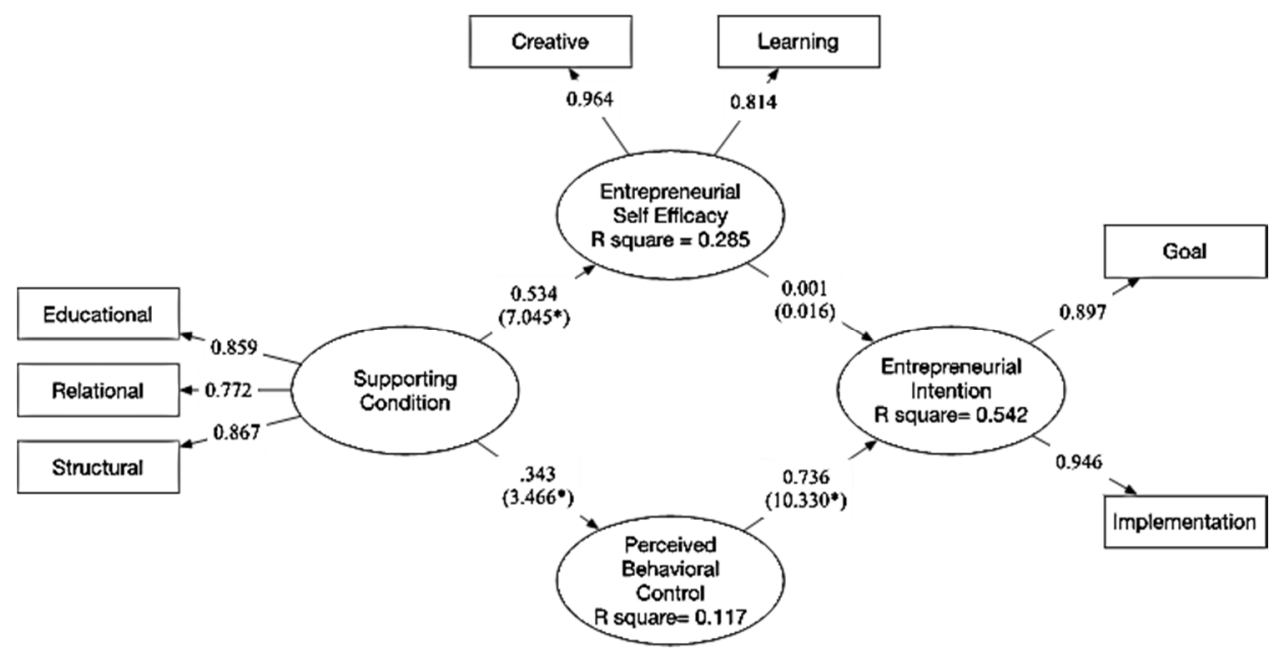

Figure 2. Partial least square (PLS) path model assessment Source: own study from Smart-PLS Output, 2019.

Table 3. Indirect effect Path Analysis

\begin{tabular}{|l|l|l|l|}
\hline \multicolumn{1}{|c|}{ Indirect } & Loading & t-test & \multicolumn{1}{|c|}{ Sig. } \\
\hline supp. condition -> Entre. Self. Effic $->$ Entre. Intention & 0.001 & 0.015 & No \\
\hline supp. condition -> perc. Behav. Control -> Entre. Intention & 0.252 & 3.461 & Yes \\
\hline
\end{tabular}

Significant at 0.05 .

Source: own study from Smart-PLS Output, 2019.

\section{Discussion}

Cultivating entrepreneurship culture has become a predominant topic for increasing the number of independent businesses. This study extends the related factors that form entrepreneurial intentions among university students. The intention to become an entrepreneur does not begin simply because people think that it can be done. To create a powerful intention requires comprehensive cognitive thinking of a feasibility analysis for a business (Fuller et al., 2018).

This study proposes the foundations of cognitive processes of entrepreneurial intention creation through the following factors: the supporting condition of surrounding stakeholders, the entrepreneurial self-efficacy, and the perceived behavioural control.

The results of this study demonstrated that, among the supporting condition factor, the structural support was seen as the primary contributor, followed by the university support and relational support. While the university appeared to be the runner up for the supporting condition, its role is undeniable (Kalitanyi \& Bbenkele, 2019). Universities should provide a more involved program, such as an integrated curriculum that combines not only theoretical educational content but also fosters creative thinking (Yurtkoru et al., 2014).

From the analysis above, the supporting conditions were considered as a factor that can increase the entrepreneurial self-efficacy more than perceived behavioural control. A well established and supportive environment could increase an individual's confidence 
based on the knowledge and understanding of a particular topic, which, in this study, was entrepreneurship (Parkinson, David, \& Rundle-Thiele, 2017). Individuals expect more when they have sufficient knowledge from the surrounding environment to solve future problems. However, the finding also indicated that the supporting condition could also increase the confidence of an individual to start and control a businesses based on individual performance. The existing environment could impress the individual to perceive that they can control the business with the existing support (Turker \& Selcuk, 2009).

However, this finding does not support the findings in Istanbul, due to different governmental policies (Yurtkoru et al., 2014). The findings in Istanbul indicated that funding support from the government without a sufficient learning program could result in the business going nowhere. The difference with the Indonesian government policy (under the Ministry of Cooperatives and SMEs), lies with various integrated programs to support the local businesses, including the financing, networking, ease of information sharing, SMEs awards, SMEs exhibitions, SMEs competitions, and many programs that support businesses to promote and sell products across the islands.

Those programs were developed not only to increase the confidence level of existing business owners but also with an intent to invite potential new business owners into the systems. The collaboration across ministries in Indonesia can reliably improve the students eager in developing their entrepreneurial skills, as realized by the competition event and fundraising program initiated by the government. These are mainly under the Ministry of Education and Culture under the Directorate of Higher Education.

A highly confident individual, as mentioned by many researchers, could increase the intention among university students to start their business (Fuller et al., 2018; Kalitanyi \& Bbenkele, 2019; Yurtkoru et al., 2014). The confidence level of the student on entrepreneurship was measured using two distinct constructs from the behavioural theories. These are the entrepreneurial self-efficacy, which reflects the individual's expectation on business performance based on their knowledge, and the perceived behavioural control, which is a belief that a business will run based on the individual characters who run it (Parkinson et al., 2017).

Parkinson et al. (2017), also mentioned that intentional behaviour is better measured by self-efficacy than by perceived behavioural control. Based on the findings in this study, there was no effect of entrepreneurial self-efficacy on entrepreneurial intention. This demonstrates that a knowledgeable individual does not merely increase their intention to start a business. The wide range of business activities required in initiating a new business is a common issue, and while self-efficacy alone could sufficiently understand the feasibility, a strong personal belief to control and adapt to the future problems is also necessary (Fuller et al., 2018; Karimi et al., 2014).

On the other hand, there are many studies that indicated that the ability to analyse and understand a business is essential in order to increase the confidence level to become entrepreneurs (Doanh \& Bernat, 2019; Kalitanyi \& Bbenkele, 2019; Laguía et al., 2019). From the results above, we conclude that the level of confidence level, supporting condition, and individual characteristics may differ across the nation and thus resulted in different results of the study. Therefore, the implications and limitations of this study are presented in the conclusion remarks below. 


\section{CONCLUSIONS}

This study on entrepreneurial intention was conducted to lend more perspective in understanding the intentions of university students in starting their own businesses. Universities are expected to provide further resources for entrepreneurial endeavors by adding entrepreneurship programs in their curricula. In a developing country like Indonesia, creating a small business has become one of the government concerns to support social welfare independently rather than relying on large scale business. Thus, society is expected to be economically independent.

This study found that the supporting condition of the surrounding environment is one of the main points that could increase a student's belief in establishing their own business. The support of the government, educational institution, and other related stakeholders is not sufficient to increase the student's interest in starting their own business, particularly for women. This study proposed that there is a gender-related reason that results in women in developing countries tending to be passive in building their own business. Instead of creating their own business, they tend to rely on a man, who is often considered as the head of the family in developing countries, and is responsible for fulfilling the family necessities.

This study has some implications regarding the results described above. Universities in Indonesia have included entrepreneurial content into their curricula, hoping the students will be not only prepared to enter the job market for large companies but also that they will gain the intent to start their own businesses. As a consequence, the universities must also pay attention not only to the theoretical aspects of business but also create a more supportive environment, cooperating with other stakeholders, including the government and existing local business owners. For governments, the cooperation with an educational institution and local business owners needs to be enhanced to scale up the program effectively. The business owners could also benefit from the universities, gaining help to understand recent data trends and the ways to innovate to maintain their business.

However, this study has certain limitations. First, though the intention is to measure future behaviour, the perception of an individual can change over time, especially after the business trial and even after graduation. Second, there is limited research comparing the entrepreneurial self-efficacy and perceived behavioural control, thus requiring more supportive results for these conclusions. Third, the role of individual characteristics may create different results. Thus, we recommend several recommendations for future research. Future studies need to administer longitudinal research and qualitative research to understand the shifts of behavioural changes among respondents. Researchers should also discuss the role of individual characteristics in entrepreneurial intentions more specifically. Finally, the research could be expanded by comparing the samples across the border by selecting the appropriate criteria with Indonesia to make the results more comparable.

\section{REFERENCES}

Adelekan, S.A., Williamson, M., Atiku, S.O., \& Ganiyu, I.O. (2018). Mediating Influence of Self-Efficacy in the Development of Entrepreneurial Intentions among Undergraduates. Jounal of Accounting and Management, 8(3), 14-26.

Ajzen, I. (2002). Constructing a TPB Questionnaire: Conceptual and Methodological Considerations. 
Retrieved from http://people.umass.edu/aizen/pdf/tpb.measurement.pdf on 15 August, 2019.

Amaro, S., \& Seabra, C. (2015). Comparing CB-SEM and PLS-SEM Results: An empirical example. In 2nd International Symposium on Partial Least Squares Path Modeling - the Conference for PLS Users. Sevilla: Catedra Metropol Parasol. https://doi.org/http://dx.doi.org/10.3990/2.357

Bandura, A., Freeman, W.H., \& Lightsey, R. (1997). Self-Efficacy: The Exercise of Control. Journal of Cognitive Psychotherapy, 13(2), 158-166. https://doi.org/10.1891/0889-8391.13.2.158

Baron, R.M., \& Kenny, D.A. (1986). The moderator mediator variable distinction in social psychological research: Conceptual strategic and statistical considerations. Journal of Personality and Social Psychology, 51(6), 1173-1182. https://doi.org/10.1037/00223514.51.6.1173

Davis, S.M. (2011). Social Entrepreneurship: Towards an Entrepreneurial Culture for Social and Economic Development. SSRN Electronic Journal. https://doi.org/10.2139/ssrn.978868

Directorate of Cooperatives and SME's Development. (2016). Warta KUMKM. Jakarta. Retrieved from https://www.bappenas.go.id/files/8014/8116/6753/Warta_KUMKM_2016_Vol_5_No_1.pdf on December 25, 2019.

Doanh, D.C., \& Bernat, T. (2019). Entrepreneurial self-efficacy and intention among Vietnamese students: A meta-analytic path analysis based on the theory of planned behaviour. Procedia Computer Science, 159, 2447-2460. https://doi.org/10.1016/j.procs.2019.09.420

Engle, R.L., Dimitriadi, N., Gavidia, J.V., Schlaegel, C., Delanoe, S., Alvarado, I., He, X., Buame, S., Wolff, B. (2010). Entrepreneurial intent: A twelve-country evaluation of Ajzen's model of planned behavior. Team Performance Management, 16(1), 35-57. https://doi.org/10.1108/13552551011020063

Esfandiar, K., Sharifi-Tehrani, M., Pratt, S., \& Altinay, L. (2019). Understanding entrepreneurial intentions: A developed integrated structural model approach. Journal of Business Research, 94, 172-182. https://doi.org/10.1016/j.jbusres.2017.10.045

Fayolle, A., Gailly, B., \& Lassas-Clerc, N. (2006). Assessing the impact of entrepreneurship education programmes: A new methodology. Journal of European Industrial Training, 30(9), 701-720. https://doi.org/10.1108/03090590610715022

Franke, N., \& Lüthje, C. (2004). Entrepreneurial intentions of business students - A benchmarking study. International Journal of Innovation and Technology Management, 1(3), 269-288. https://doi.org/10.1142/S0219877004000209

Fuller, B., Liu, Y., Bajaba, S., Marler, L.E., \& Pratt, J. (2018). Examining how the personality, self-efficacy, and anticipatory cognitions of potential entrepreneurs shape their entrepreneurial intentions. Personality and Individual Differences, 125, 120-125. https://doi.org/10.1016/j.paid.2018.01.005

Greblikaite, J., Sroka, W., \& Gerulaitiene, N. (2016). Involving young people in Polish and Lithuanian social enterprises by fostering entrepreneurial skills and abilities as entrepreneurial opportunity at university. Entrepreneurial Business and Economics Review, 4(3), 131-152. https://doi.org/10.15678/EBER.2016.040310

Hair, J.F., Ringle, C.M., \& Sarstedt, M. (2011). PLS-SEM: Indeed a Silver Bullet. The Journal of Marketing Theory and Practice, 19(2), 139-152. https://doi.org/10.2753/MTP1069-6679190202

Hair, J. F., Ringle, C.M., \& Sarstedt, M. (2013). Partial Least Squares Structural Equation Modeling: Rigorous Applications, Better Results and Higher Acceptance. Long Range Planning, 46(1-2), 1-12. https://doi.org/10.1016/j.Irp.2013.01.001

Hair, J. F., Risher, J.J., Sarstedt, M., \& Ringle, C.M. (2019). When to use and how to report the results of PLS-SEM. European Business Review, 31(1), 2-24. https://doi.org/10.1108/EBR-11-2018-0203

Hajli, N. (2015). Social commerce constructs and consumer's intention to buy. International Journal of Information Management, 35(2), 183-191. https://doi.org/10.1016/j.ijinfomgt.2014.12.005 
Hajli, N., \& Lin, X. (2016). Exploring the Security of Information Sharing on Social Networking Sites: The Role of Perceived Control of Information. Journal of Business Ethics, 133(1), 111-123. https://doi.org/10.1007/s10551-014-2346-x

Hayes, A.F. (2009). Beyond Baron and Kenny: Statistical Mediation Analysis in the New Millennium. Communication Monographs, 76(4), 408-420. https://doi.org/10.1080/03637750903310360

Henderson, R., \& Robertson, M. (1999). Who wants to be an entrepreneur? Young adult attitudes to entrepreneurship as a career. Education \& Training, 41(5), 236-245. https://doi.org/10.1108/00400919910279973

Heuer, A., \& Kolvereid, L. (2014). Education in entrepreneurship and the theory of planned behaviour. European Journal of Training and Development, 38(6), 506-523. https://doi.org/10.1108/EJTD-02-2013-0019

Huang, J., \& Zhou, L. (2018). Timing of web personalization in mobile shopping: A perspective from Uses and Gratifications Theory. Computers in Human Behavior, 88, 103-113. https://doi.org/10.1016/j.chb.2018.06.035

Kalitanyi, V., \& Bbenkele, E. (2019). Measuring University Students' Perceptions About the Role of Self-efficacy on Entrepreneurial Intentions in Cape Town. Journal of Entrepreneurship and Innovation in Emerging Economies, 5(2), 1-19. https://doi.org/10.1177/2393957519863900

Karimi, S., Biemans, H.J.A., Lans, T., Chizari, M., \& Mulder, M. (2014). The Impact of Entrepreneurship Education: A Study of Iranian Students' Entrepreneurial Intentions and Opportunity Identification. Journal of Small Business Management, 54(1), 187-209. https://doi.org/10.1111/jsbm.12137

Kelley, D.J., Singer, S., \& Herrington, M. (2012). 2011 Global Report (The Global Entrepreneurship Monitor). Retrieved from https://www.gemconsortium.org/report/gem-2011-global-report, on 23 August 2019.

Krueger, N.F., \& Carsrud, A.L. (1993). Entrepreneurial intentions: Applying the theory of planned behaviour. Entrepreneurship and Regional Development, 5(4), 315-330. https://doi.org/10.1080/08985629300000020

Laguía, A., Moriano, J.A., \& Gorgievski, M.J. (2019). A psychosocial study of self-perceived creativity and entrepreneurial intentions in a sample of university students. Thinking Skills and Creativity, 31(March 2019), 44-57. https://doi.org/10.1016/j.tsc.2018.11.004

Liñán, F. (2008). Skill and value perceptions: How do they affect entrepreneurial intentions?. International Entrepreneurship and Management Journal, 4(3), 257-272. https://doi.org/10.1007/s11365-008-0093-0

Liñán, F., \& Chen, Y.W. (2009). Development and cross-cultural application of a specific instrument to measure entrepreneurial intentions. Entrepreneurship: Theory and Practice, 33(3), 593-617. https://doi.org/10.1111/j.1540-6520.2009.00318.x

Mat, S.C., Maat, S.M., \& Mohd, N. (2015). Identifying Factors that Affecting the Entrepreneurial Intention among Engineering Technology Students. Procedia - Social and Behavioral Sciences, 211, 1016-1022. https://doi.org/10.1016/j.sbspro.2015.11.135

Ministry of Cooperatives and SMEs. (2016). PERKEMBANGAN DATA USAHA MIKRO, KECIL, MENENGAH (UMKM) DAN USAHA BESAR (UB) TAHUN 2010 - 2015. Retrieved from http://www.depkop.go.id/uploads/laporan/1562040307_SANDINGAN_DATA_UMKM_20102015_.pdf on December 25, 2019 
Ministry of Cooperatives and SME'S. (2018). PERKEMBANGAN DATA USAHA MIKRO, KECIL, MENENGAH (UMKM) DAN USAHA BESAR (UB) TAHUN 2016-2017. Retrieved from http://www.depkop.go.id/uploads/laporan/1549946778_UMKM 2016-2017 rev.pdf, on December 25, 2019.

Moriano, J.A., Gorgievski, M., Laguna, M., Stephan, U., \& Zarafshani, K. (2012). A Cross-Cultural Approach to Understanding Entrepreneurial Intention. Journal of Career Development, 39(2), 162-185. https://doi.org/10.1177/0894845310384481

Natalia, C., \& Rodhiah. (2019). Pengaruh Kreativitas, Edukasi Dan Efikasi Diri Terhadap Intensi Berwirausaha Dalam Generasi Z. Jurnal Manajerial Dan Kewirausahaan, 1(2), 164-171.

Okręglicka, M., Havierniková, K., Mynarzová, M., L.-M.A. (2013). Entrepreneurial Intention Creation of Students in Poland, Slovakia and Czechia. Polish Journal of Management Studies, 8(7), 288297. https://doi.org/10.17512/pjms.2017.15.2.15

Parkinson, J., David, P., \& Rundle-Thiele, S. (2017). Self-efficacy or perceived behavioural control: Which influences consumers' physical activity and healthful eating behaviour maintenance? Journal of Consumer Behaviour, 16(5), 413-423. https://doi.org/10.1002/cb.1641

Qiao, X., \& Huang, J.-H. (2019). Effect of College Students' Entrepreneurial Self-Efficacy on Entrepreneurial Intention: Career Adaptability as a Mediating Variable. International Journal of Educational Methodology, 5(3), 305-313. https://doi.org/10.12973/ijem.5.3.305

Saeed, S., Yousafzai, S.Y., Yani-De-Soriano, M., \& Muffatto, M. (2015). The Role of Perceived University Support in the Formation of Students' Entrepreneurial Intention. Journal of Small Business Management, 53(4), 1127-1145. https://doi.org/10.1111/jsbm.12090

Sentanu, I.G.E.P.S., Zamrudi, Z., \& Praharjo, A. (2019). Consumer Generated Media: Understanding Indonesian Social Traveller. Journal of Physics: Conference Series, 1175. https://doi.org/10.1088/1742-6596/1175/1/012221

Straub, D., Boudreau, M.-C., \& Gefen, D. (2004). Validation Guidelines for Is Positivist. Communications of the Association for Information Systems, 13. https://doi.org/10.17705/1CAIS.01324

Turker, D., \& Selcuk, S.S. (2009). Which factors affect entrepreneurial intention of university students?. Journal of European Industrial Training, 33(2), 142-159. https://doi.org/10.1108/03090590910939049

Venema, E., Otten, S., \& Vlaskamp, C. (2015). The efforts of direct support professionals to facilitate inclusion: the role of psychological determinants and work setting. Journal of Intellectual Disability Research, 59(10), 970-979. https://doi.org/10.1111/jir.12209

Wong, K.K. (2013). Partial Least Squares Structural Equation Modeling (PLS-SEM) Techniques Using SmartPLS. Marketing Bulletin, 24(1), 1-32. Retrieved from http://marketingbulletin.massey.ac.nz/v24/mb_v24_t1_wong.pdf, on 23 March 2018.

Yurtkoru, E.S., Kabadayı Kuşcu, Z., \& Doğanay, A. (2014). Exploring the Antecedents of Entrepreneurial Intention on Turkish University Students. Procedia - Social and Behavioral Sciences, 150, 841-850. https://doi.org/10.1016/j.sbspro.2014.09.093

Zamrudi, Z., Karim, S., Faridha, M., Maharani, D., \& Kuraesin, A. D. (2019). Smart meter adoption: The role of consumer experience in using smart device. Journal of Physics: Conference Series, 1175, 1-6. https://doi.org/10.1088/1742-6596/1175/1/012038

Zhao, H., Hills, G.E., \& Seibert, S.E. (2005). The mediating role of self-efficacy in the development of entrepreneurial intentions. Journal of Applied Psychology, 90(6), 1265-1272. https://doi.org/10.1037/0021-9010.90.6.1265 
Appendix A: Items constituting the measuring question instrument

\begin{tabular}{|c|c|c|}
\hline Sources & Code & Constructs \\
\hline \multirow{4}{*}{$\begin{array}{l}\text { Educational (Kalitanyi \& } \\
\text { Bbenkele, 2019; Yurtkoru et } \\
\text { al., 2014) }\end{array}$} & ed1 & $\begin{array}{l}\text { The campus program supports the development of student } \\
\text { entrepreneurship }\end{array}$ \\
\hline & ed2 & $\begin{array}{l}\text { Development of entrepreneurial knowledge and abilities by } \\
\text { the campus }\end{array}$ \\
\hline & ed3 & $\begin{array}{l}\text { Availability of scientific support on entrepreneurship by the } \\
\text { campus }\end{array}$ \\
\hline & ed4 & Availability of entrepreneurship development laboratories \\
\hline \multirow{3}{*}{$\begin{array}{l}\text { Relational (Venema et al., } \\
\text { 2015; Yurtkoru et al., 2014) }\end{array}$} & rel1 & Support from friends around for entrepreneurship \\
\hline & rel2 & Support from family about entrepreneurship \\
\hline & rel3 & Supporting the environment for entrepreneurship \\
\hline \multirow{3}{*}{$\begin{array}{l}\text { Structural (Venema et al., } \\
\text { 2015; Yurtkoru et al., 2014) }\end{array}$} & str1 & $\begin{array}{l}\text { Support from the local government for student entrepreneur- } \\
\text { ship }\end{array}$ \\
\hline & str2 & $\begin{array}{l}\text { Support from the private sector for the development of stu- } \\
\text { dent entrepreneurship }\end{array}$ \\
\hline & str3 & $\begin{array}{l}\text { Support from entrepreneurial organizations (example: HIPMI) } \\
\text { for the development of student entrepreneurship }\end{array}$ \\
\hline \multirow{7}{*}{$\begin{array}{l}\text { Creativity (Esfandiar et al., } \\
\text { 2019; Zhao et al., 2005) }\end{array}$} & cre1 & Ability to provide solutions \\
\hline & cre2 & The ability to make various alternative solutions \\
\hline & cre3 & Willingness to communicate ideas \\
\hline & cre4 & Often providing solutions ahead of others \\
\hline & cre5 & The ability to translate ideas to colleagues \\
\hline & cre6 & The level of motivation in creating ideas \\
\hline & cre7 & Feelings when thinking about new ideas \\
\hline \multirow{4}{*}{$\begin{array}{l}\text { Learning (Yurtkoru et al., } \\
\text { 2014; Zhao et al., 2005) }\end{array}$} & Irn1 & Ability to manage activities during deadlines \\
\hline & Irn2 & Ability to understand problems \\
\hline & Irn3 & $\begin{array}{l}\text { The ability to map the sequence of events (systematic) prob- } \\
\text { lems }\end{array}$ \\
\hline & Irn4 & Memory of an entrepreneurial concept \\
\hline \multirow{6}{*}{$\begin{array}{l}\text { Perceived Behavioural Con- } \\
\text { trol (Natalia \& Rodhiah, 2019; } \\
\text { Qiao \& Huang, 2019; Yurtkoru } \\
\text { et al., 2014) }\end{array}$} & pbc1 & Confidence in starting a decent business \\
\hline & pbc2 & The ability to handle business processes in a business \\
\hline & pbc3 & Detailed knowledge of business management in practice \\
\hline & pbc4 & Knowledge in developing small and medium business projects \\
\hline & pbc5 & Feelings about success in the future business field \\
\hline & pbc6 & Feelings about the ease of starting a business and running it \\
\hline \multirow{2}{*}{$\begin{array}{l}\text { Goal (Huang \& Zhou, 2018; } \\
\text { Qiao \& Huang, 2019; } \\
\text { Yurtkoru et al., 2014) }\end{array}$} & gol1 & Desire to become an entrepreneur \\
\hline & gol2 & Totality in designing a business \\
\hline \multirow{3}{*}{$\begin{array}{l}\text { Implementation (Natalia \& } \\
\text { Rodhiah, 2019; Qiao \& Huang, } \\
\text { 2019; Zhao et al., 2005) }\end{array}$} & imp1 & Determination to become an entrepreneur \\
\hline & imp2 & Desire in planning a business \\
\hline & imp3 & The possibility to start a business in the near future \\
\hline
\end{tabular}




\section{Authors}

Zakky Zamrudi prepared the introduction, literature review and material and methods, while Farida Yulianti processed the statistical analysis, and prepared results and discussion and the conclusions.

\section{Zakky Zamrudi}

Assistant Professor in the Department of Management Studies; junior lecturer in the Depart-ment of Management and +Business Studies at Islamic University of Kalimantan; Editor in national journal 'AtTadbir: jurnal ilmiah manajemen'; Reviewer in information and technology journal; author of publications on information systems, technology acceptance, and technology innovation for business.

Correspondence to: Zakky Zamrudi, Islamic University of Kalimantan, Jl. Adhyaksa No. 2 Kayutangi, Banjarmasin, Indonesia, e-mail: zakky@uniska-bjm.ac.id ; jzakky@gmail.com

ORCID (ㄱ) http://orcid.org/0000-0003-4483-2311

\section{Farida Yulianti}

Associate Professor in the Department of Management Studies; Dean of Faculty of Economics and Business studies; senior lecturer at Islamic University of Kalimantan; author of publications on marketing studies, buying behaviour, and youngster behavioural intentions.

Correspondence to: Farida Yulianti, Islamic University of Kalimantan, Jl. Adhyaksa No. 2 Kayutangi, Banjarmasin, Indonesia, e-mail: farida.yulianty@yahoo.com

ORCID (1) http://orcid.org/0000-0003-3708-2452

\section{Acknowledgements and Financial Disclosure}

A great thanks is given to the research team, who was the class members of 2017 coordinated by Nispu Faradina. This research is supported by Islamic University of Kalimantan under the supervisory of Bureau of Research and Community Services.

\section{Copyright and License}

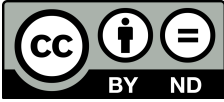

This article is published under the terms of the Creative Commons

Attribution - NoDerivs (CC BY-ND 4.0) License http://creativecommons.org/licenses/by-nd/4.0/

\section{Published by the Centre for Strategic and International Entrepreneurship - Krakow, Poland}


